\title{
Calculation of a Methane C-H Oxidative Addition Trajectory: Comparison to Experiment and Methane Activation by High-Valent Complexes
}

\author{
Thomas R. Cundari ${ }^{1}$ \\ Contribution from the Department of Chemistry, Memphis State University, \\ Memphis, Tennessee 38152
}

Received March 4, $1993^{\circ}$

\begin{abstract}
An effective core potential (ECP), parallel supercomputing study of methane activation by 14-electron, $\mathrm{Ir}\left(\mathrm{PH}_{3}\right)_{2}(\mathrm{X})$ complexes $(\mathrm{X}=\mathrm{H}, \mathrm{Cl})$ is presented. Considerable weakening of the coordinated methane $\mathrm{C}-\mathrm{H}$ bond occurs upon formation of an $\eta^{2}-\mathrm{CH}$ coordinated $(\mathrm{X})\left(\mathrm{PH}_{3}\right)_{2} \mathrm{Ir} \ldots \mathrm{HCH}_{3}$ adduct. A more strongly bound adduct (with greater weakening of the coordinated $\mathrm{C}-\mathrm{H}$ bond) occurs when $\mathrm{X}=\mathrm{Cl}$ versus $\mathrm{X}=\mathrm{H}$. The calculated $\operatorname{Ir}\left(\mathrm{PH}_{3}\right)_{2}(\mathrm{H})$ $+\mathrm{CH}_{4} \rightarrow \operatorname{Ir}\left(\mathrm{PH}_{3}\right)_{2}(\mathrm{H})_{2}(\mathrm{Me})$ reaction enthalpy is $-12.8 \mathrm{kcal} \mathrm{mol}^{-1}$, and $-41.6 \mathrm{kcal} \mathrm{mol}^{-1}$ for the chloro analogue. The intrinsic reaction coordinate is calculated and compared to an experimental trajectory. Analysis of the wave function along the intrinsic reaction coordinate (IRC) suggests that although donation of electron density from methane to metal is essential for adduct formation, it is not until backdonation to $\sigma^{*}{ }_{\mathrm{CH}}$ increases that the $\mathbf{C}-\mathbf{H}$ bond is activated and cleaved. The electronic and molecular structure of the reacting system along the IRC suggest a two-stage mechanism: substrate to complex donation is important in the early part of the reaction (electrophilic stage) while complex to substrate backdonation is necessary later on (nucleophilic stage) for $\mathrm{C}-\mathrm{H}$ scission. Finally, comparison of IRCs for low- and high-valent methane-activating complexes shows similar topology in the early portion of the activation event; differentiation between oxidative addition and $\sigma$-bond metathesis occurs at the point at which there is a shift from the electrophilic to nucleophilic stage of the reaction.
\end{abstract}

\section{Introduction}

Selective $\mathrm{C}-\mathrm{H}$ activation of methane by transition metal and lanthanide complexes has been the subject of considerable study as a result of its importance in catalytic methane conversion. ${ }^{2}$ Two main strategies have been pursued to effect concerted (as opposed to nonconcerted radical $^{3}$ or electrophilic ${ }^{4}$ activation) $\mathrm{C}-\mathrm{H}$ activation in homogeneous systems: oxidative addition ${ }^{5}$ and $\sigma$-bond metathesis. ${ }^{6} \sigma$-Bond metathesis involves 1,2 -addition of $\mathrm{C}-\mathrm{H}$ across an appropriate metal-ligand bond (single or multiple) and is effected by high-valent ( $\mathrm{d}^{0}$ and $\mathrm{d}^{0} \mathrm{f}^{n}$ ) complexes. ${ }^{6}$ Representative examples of high-valent, methane-activated complexes are $\mathrm{Cp}_{2}{ }_{2} \mathrm{LuCH}_{3},{ }^{7}\left(\mathrm{NHSi}^{\prime}\right)_{2} \mathrm{Zr}=\mathrm{NSi}^{\prime}\left(\mathrm{Si}^{\prime}=\mathrm{Si}(t-\mathrm{Bu})_{3}\right),{ }^{8}$ and thoracyclobutanes. ${ }^{9}$ Oxidative addition entails 1,1 -addition of $\mathrm{C}-\mathrm{H}$ to a low-valent transition metal and results in an increase in the formal oxidation state and coordination number of the metal by two units. ${ }^{5}$ The 16 -electron $C p^{*} M(L)(M=R h, I r ; L$ $=\mathrm{PR}_{3}, \mathrm{CO}$ ) intermediates ${ }^{5,10}$ are perhaps the best known examples of complexes for which oxidative addition is the putative $\mathrm{C}-\mathrm{H}$ activation mechanism.

- Abstract published in Advance ACS Abstracts, September 15, 1993 (1) e-mail: cundarit@ memstvxl.memst.edu.

(2) (a) Activation and Functionalization of Alkanes; Hill, C. L., Ed.; Wiley: New York, 1989. (b) Saillard, J. Y. In Selective Hydrocarbon Activation; Davies, J. A., Ed.; VCH: New York, 1990; p 207. (c) A good discussion of the requirements for a successful methane conversion catalyst from an industrial point of view can be found in: Parkyns, N. D. Chem. Br. $1990,9,841$.

(3) (a) Khenkin, A. M.; Shilov, A. E. New J. Chem. 1989, 13, 659. (b)

Liu, H. F.; Liu, K. Y.; Liew, R. E.; Lunsford, J. H. J. Am. Chem. Soc. 1984 106,4117 .

(4) Olah, G. A. Acc. Chem. Res. 1987, $20,422$.

(5) Jones, W. D. In ref $2 a, p 11$.

(6) Rothwell, I. P. In ref $2 a, p 151$

(7) Watson, P. L. J. Am. Chem. Soc. 1983, 105, 6491.

(8) Cummins, C. C.; Baxter, S. M.; Wolczanski, P. T. J. Am. Chem. Soc. 1988, 110,8731 .

(9) Fendrick, C. M.; Marks, T. J. J. Am. Chem. Soc. 1984, 106, 2214

(10) (a) Janowicz, A. H.; Bergman, R. G. J. Am. Chem. Soc. 1982, 104, 352. (b) Hoyano, J. K.; Graham, W. A. G. J. Am. Chem. Soc. 1982, 104 3723. (c) Jones, W. D.; Feher, F. J. J. Am. Chem. Soc. 1982, 104, 4240. (d) A review of the research on 16-electron CpML C-H activators can be found in ref 5 and: Jones, W. D.; Feher, F. J. Acc. Chem. Res. 1989, 22, 91.
Another family of low-valent, $\mathrm{C}-\mathrm{H}$-activating complexes are 14-electron species of the general form $\mathrm{M}(\mathrm{L})_{n}\left(\mathrm{PR}_{3}\right)_{m}$, where $\mathrm{L}$ is a univalent ligand such as hydrido, chloro, or an $\eta^{1}$-carboxylate group. ${ }^{11,12}$ As Crabtree has pointed out, ${ }^{11}$ 14-electron complexes have advantages over 16 -electron species from the point of view of building a catalyst system. The hydrido(alkyl) complex, eq $1 \mathrm{a}$, is still electron-deficient (i.e., 16-electron), typically with

$$
\begin{gathered}
\mathrm{L}_{n} \mathrm{M}+\mathrm{R}-\mathrm{CH}_{2}-\mathrm{CH}_{3} \rightarrow \mathrm{L}_{n} \mathrm{M}(\mathrm{H})\left(\mathrm{CH}_{2}-\mathrm{CH}_{2}-\mathrm{R}\right) \\
\mathrm{L}_{n} \mathrm{M}(\mathrm{H})\left(\mathrm{CH}_{2}-\mathrm{CH}_{2}-\mathrm{R}\right) \rightarrow \mathrm{L}_{n}(\mathrm{H})_{2}\left(\mathrm{H}_{2} \mathrm{C}=\mathrm{C}(\mathrm{H}) \mathrm{R}\right) \\
\mathrm{L}_{n}(\mathrm{H})_{2}\left(\mathrm{H}_{2} \mathrm{C}=\mathrm{C}(\mathrm{H}) \mathrm{R}\right) \rightarrow \mathrm{L}_{n} \mathrm{M}(\mathrm{H})_{2}+\mathrm{H}_{2} \mathrm{C}=\mathrm{C}(\mathrm{H}) \mathrm{R} \\
\mathrm{L}_{n} \mathrm{M}(\mathrm{H})_{2} \rightarrow \mathrm{L}_{n} \mathrm{M}+\mathrm{H}_{2}
\end{gathered}
$$

vacant coordination sites, allowing for $\beta$ - $\mathrm{H}$ transfer to form an 18-electron bis(hydrido)olefin, eq $1 \mathrm{~b}$, which can dissociate olefin to yield a bis(hydrido) complex, eq 1c. The bis(hydrido) complex can regenerate the reactive intermediate either by photolytic dissociation of $\mathrm{H}_{2}$ or by addition of an $\mathrm{H}_{2}$ scavenger (e.g., tertbutylethylene), eq 1d."1 Crabtree $^{11,12 a}$ has developed an alkane dehydrogenation catalyst starting from $\operatorname{Ir}(\mathrm{H})_{2}\left(\eta^{2}\right.$-carboxylate) $\left(\mathrm{PR}_{3}\right)_{2}$; the reactive intermediate is thought to be the 14electron $\operatorname{Ir}\left(\mathrm{PR}_{3}\right)_{2}\left(\eta^{1}\right.$-carboxylate). Sakakura and Tanaka ${ }^{12 \mathrm{c}}$ have studied catalytic alkane carbonylation by a $\mathrm{R}$ h catalyst; the $\mathrm{C}-\mathrm{H}$ activating species is thought to be $\mathrm{Rh}(\mathrm{Cl})\left(\mathrm{PR}_{3}\right)_{2}$. Recently, Schulz and Werner ${ }^{12 d}$ have studied the rearrangement between vinyl(hydride) complexes and olefin isomers of $\operatorname{Ir}\left(P R_{3}\right)_{2}-$ (Cl) $\left(\mathrm{C}_{2} \mathrm{H}_{4}\right)$.

(11) Crabtree, R. H. In ref $2 a, p 69$.

(12) (a) Burk, M. J.; Crabtree, R. H. J. Am. Chem. Soc. 1987, 109, 8025 (b) Cameron, C. J.; Felkin, H.; Fillebeen-Khan, T.; Forrow, N. J.; Guittet, E. J. Chem. Soc., Chem. Commun. 1986, 801. (c) Sakakura, T.; Tanaka, M. Chem. Lett. 1987, 249, 1113. Sakakura, T.; Tanaka, M.J. Chem. Soc., Chem. Commun. 1987, 758. (d) Schulz, M.; Werner, H. Organometallics 1992, 11 , 2790. 
Computational studies of oxidative addition (and the reverse, reductive elimination) have shed considerable light on mechanistic details. ${ }^{2 b}$ Seminal among the contributions are the studies of Saillard and Hoffmann ${ }^{13}$ as well as Low and Goddard. ${ }^{14}$ Koga and Morokuma ${ }^{15}$ have studied methane activation by $\mathrm{Rh}(\mathrm{Cl})$ $\left(\mathrm{PH}_{3}\right)_{2}$ to form $\mathrm{Rh}(\mathrm{Cl})(\mathrm{H})(\mathrm{Me})\left(\mathrm{PH}_{3}\right)_{2}$. Density functional methods have been used by Ziegler et al. ${ }^{16}$ to look at oxidative addition of methane to 16-electron $\mathrm{CpM}(\mathrm{L})(\mathrm{M}=\mathrm{Ir}, \mathrm{Rh} ; \mathrm{L}=$ $\left.\mathrm{CO}, \mathrm{PH}_{3}\right)$ species. Extended Hückel theory has been used to probe activation of ethylene $\mathrm{C}-\mathrm{H}$ bonds by $\mathrm{CpIr}\left(\mathrm{PH}_{3}\right)$ and $\mathrm{Cp} * \operatorname{Ir}\left(\mathrm{PMe}_{3}\right) .{ }^{17}$

As part of a continuing focus on transition metal bonding and reactivity, ${ }^{18}$ a study of the important $\mathrm{C}-\mathrm{H}$ activation reaction, eq 2, was undertaken. For the present, the focus is on $\mathbf{C}-\mathrm{H}$

$$
\operatorname{Ir}\left(\mathrm{PH}_{3}\right)_{2}(\mathrm{X})+\mathrm{CH}_{3}-\mathrm{H} \rightarrow \operatorname{Ir}\left(\mathrm{PH}_{3}\right)_{2}(\mathrm{X})\left(\mathrm{CH}_{3}\right)(\mathrm{H})
$$

activation by 14-electron complexes of the form $\operatorname{Ir}\left(\mathrm{PH}_{3}\right)_{2}(\mathrm{X})$, where $\mathrm{X}=\mathrm{H}$ and $\mathrm{Cl}^{11,12}$ In previous work ${ }^{18 \mathrm{a}}$ the concentration has been on high-valent $\mathrm{C}-\mathrm{H}$-activating systems operating through $\sigma$-bond metathesis. In order to come to a more global understanding of the $\mathrm{C}-\mathrm{H}$ activation problem, we instituted research on oxidative addition by 14-electron systems. This work also constitutes further testing of the coupling of promising new technologies (like parallel computing ${ }^{19}$ ) and methods (such as effective core potentials ${ }^{20}$ ) as answers to the challenges of computational transition metal (TM) and lanthanide (Ln) chemistry.

\section{Computational Methods}

Calculations employ the quantum chemistry program GAMESS. ${ }^{19}$ One important difference between this and previous work ${ }^{18}$ is that the GAMESS code has now been made to run in parallel on a variety of platforms. ${ }^{19}$ For this research the iPSC/860 supercomputer ( 128 nodes with $8 \mathrm{Mb}$ of memory per node) at Oak Ridge National Laboratories is utilized for parallel computations. Calculations with correlated wave functions employ the vectorized version of GAMESS and were run on the Cray Y-MP/464 at the National Center for Supercomputer Applications. The effective core potentials (ECPs) and valence basis sets of Stevens et al. ${ }^{20 \mathrm{a}}$ are used for all heavy atoms, and the $-31 \mathrm{G}$ basis set is used for H. ECPs replace the innermost core orbitals for the TMs and all core orbitals for main-group (MG) elements. Thus, the $n \mathrm{~s}, n \mathrm{p}$, $n \mathrm{~d},(n+1) \mathrm{s}$, and $(n+1) \mathrm{p}$ are treated explicitly for the d-block; for the main-group, $n \mathrm{~s}$ and $n \mathrm{p}$ are treated explicitly. In the standard implementation, TM valence basis sets are quadruple- and triple- $\zeta$ for the sp and $\mathrm{d}$ shells, respectively, while main-group elements have a double- $\zeta$ valence basis. Basis sets for heavy, main-group elements are augmented with a d polarization function in our work. Transition metal ECPs are generated from all-electron, Dirac-Fock calculations and thus include Darwin and mass velocity effects, while spin-orbit coupling is averaged out in potential generation. ${ }^{20}$ No degradation in accuracy has been found upon descending a transition metal triad toward heavier members (for which relativistic effects will be most important).

(13) Hoffmann, R.; Saillard, J. Y. J. Am. Chem. Soc. 1984, 106, 2006 (14) Low, J. J.; Goddard, W. A. J. Am. Chem. Soc. 1986, 108, 6115 and references therein.

(15) Koga, N.; Morokuma, K. J. Chem. Phys. 1990, 94, 5454.

(16) Ziegler, T. L.; Tschinke, V.; Fan, L.; Becke, A. D. J. Am. Chem. Soc. 1989, 111,9177 .

(17) (a) Stoutland, P. O.; Bergman, R. G. J. Am. Chem. Soc. 1985, 107, 4581. (b) Silvestre, J.; Calhorda, M. J.; Hoffmann, R.; Stoutland, P. O.; Bergman, R. G. Organometallics 1986, 5, 1841.

(18) (a) Cundari, T. R. J. Am. Chem. Soc. 1992, 114, 10557. (b) Cundari, T. R.; Gordon, M. S. J. Am. Chem. Soc. 1993, 115, 4210. (c) Cundari, T. R. J. Am. Chem. Soc. 1992, 114, 7879. (d) Cundari, T. R. Int. J. Quantum Chem., Proc. 1992 Sanibel Symp. 1992, 26, 793.

(19) (a) Schmidt, M. W.; Baldridge, K. K.; Boatz, J. A.; Jensen, J. H.; Koseki, S.; Gordon, M. S.; Nguyen, K. A.; Windus, T. L.; Elbert, S. T GAMESS. QCPE Bulletin, 1990, 10, 52. (b) Schmidt, M. W.; Baldridge, K. K.; Boatz, J. A.; Jensen, J. H.; Koseki, S.; Matsunaga, N.; Gordon, M. S.; Nguyen, K. A.; Su, S.; Windus, T. L.; Elbert, S. T.; Montgomery, J.; Dupuis, M. J. Comput. Chem. 1993, 14, 1347.

(20) (a) Krauss, M.; Stevens, W. J.; Basch, H.; Jasien, P. G. Can. J. Chem. 1992, 70, 612. (b) Stevens, W. J.; Cundari, T. R. J. Chem. Phys. 1993, 98 , 5555 .
Geometries are optimized at the restricted Hartree Fock (RHF) level for closed-shell singlets. Previous work ${ }^{18}$ has shown that bond lengths and angles for TM complexes (involving complexes in a variety of geometries and oxidation states and of metals from the entire transition series) are predicted to within 1-3\% of experiment using the present computational scheme.

Vibrational frequencies are calculated at stationary points to identify them as minima (zero imaginary frequencies) or transition states (one imaginary frequency). Plotting the imaginary frequencies is used to assess which TS connects which reactants and products. In some cases the intrinsic reaction coordinate (IRC) is followed using the steepest descent algorithm of Ishida et al.,21a with the stabilization method described by Schmidt et al. ${ }^{21 b}$

Although geometries are accurately predicted at the RHF level, energetics will typically be poor if correlation is ignored. For species described well at the RHF level, the correlation contribution can be treated as a perturbation of the RHF energy and calculated using Moller-Plesset second-order perturbation theory (MP2)..$^{22}$ Koga and Morokuma ${ }^{15}$ used a similar scheme in their work, as have Krogh-Jespersen et al. in studies of oxidative addition. ${ }^{23}$ A simple RHF geometry/MP2 energy scheme yielded good agreement with experimental data for high-valent $\mathrm{C}-\mathrm{H}$ activating systems, both in terms of absolute numbers and trends. ${ }^{18 a-c}$

\section{Results and Discussion}

1. Reactants. The geometry of methane is well-known. ${ }^{24}$ Reactant complexes are three-coordinate $\operatorname{Ir}(\mathrm{X})\left(\mathrm{PH}_{3}\right)_{2}$ complexes $(\mathrm{X}=\mathrm{H}, \mathrm{Cl})$, models of the putative 14-electron, $\mathrm{C}-\mathrm{H}$-activating species in dehydrogenation catalysts. ${ }^{11,12 a, b}$ As in previous computational work ${ }^{13,15-17}$ we have focused on the lowest energy, singlet surface. Geometries for bis(phosphino) $\mathrm{Ir}^{\mathrm{I}}$ chloride and bis(phosphino) $\operatorname{Ir}^{\mathrm{I}}$ hydride minima ( $C_{2}$ symmetry) are shown in 1. As expected for a $\mathrm{d}^{8} \mathrm{ML}_{3}$ complex, the geometry is $\mathrm{T}$-shaped. ${ }^{25}$

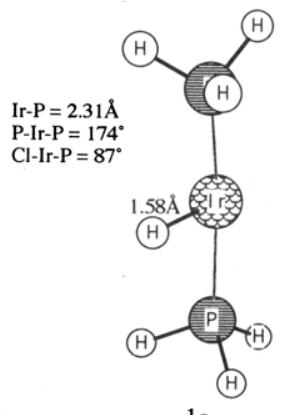

la

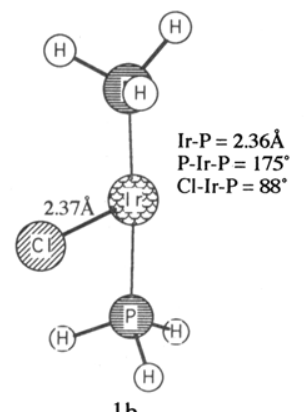

$1 b$
The cationic, five-coordinate complex trans- $\left[\operatorname{Ir}\left(\mathrm{PPh}_{3}\right)_{2}(\mathrm{CO})_{3}\right]-$ $\left[\mathrm{HSO}_{4}\right]$ has Ir-P bond lengths of 2.364(3) and 2.36393) $\AA .{ }^{26} \mathrm{In}$ "five-coordinate" $\left[\operatorname{Ir}(\mathrm{H})_{2}(8\right.$-methylquinoline $\left.)\left(\mathrm{PPh}_{3}\right)_{2}\right]\left[\mathrm{BF}_{4}\right]$ the trans phosphines have Ir-P bond lengths of 2.314(3) and 2.312(3) $\AA$; there is evidence for an agostic interaction in this complex between the metal and a $\mathrm{C}-\mathrm{H}$ on the methyl group in 8-methylquinoline. ${ }^{27}$ For $\left[\operatorname{Ir}\left(\mathrm{PPh}_{3}\right)_{2}(\mathrm{CO})(8\right.$-methylquinoline $\left.)\right]\left[\mathrm{PF}_{6}\right]$ (an $\mathrm{Ir}^{\mathrm{I}}$ formal oxidation state and coordination number of four), $\mathrm{Ir}-\mathrm{P}$ $=2.323(2)$ and $2.335(2) \AA .28$ For six-coordinate $\operatorname{Ir}(\mathrm{P}-i$ $\left.\mathrm{Pr}_{3}\right)_{2}(\mathrm{CO})(\mathrm{H})($ vinyl $)(\mathrm{Cl}),{ }^{12 \mathrm{~d}} \mathrm{Ir}-\mathrm{Cl}=2.479(2) \AA$ and $\mathrm{Ir}-\mathrm{P}=$ 2.362(1) and 2.371(1) $\AA$ for the trans phosphines; the $\mathrm{Cl}$ is trans

(21) (a) Ishida, K.; Morokuma, K.; Komornicki, A. J. Chem. Phys. 1977, 66, 2153. (b) Schmidt, M. W.; Gordon, M.S.; Dupuis, M. J. Am. Chem. Soc. 1985, 107, 2585. (c) Garrett, B. C.; Redmon, M. J.; Steckler, R.; Truhlar, D. G.; Baldridge, K. K.; Bartol, D.; Schmidt, M. W.; Gordon, M. S. J. Phys. Chem. 1989, 93, 2888.

(22) Moller, C.; Plesset, M. S. Phys. Rev. 1934, 46, 618.

(23) Abu-Hasanayn, F.; Krogh-Jespersen, K.; Goldman, A.S. Inorg. Chem. 1992, 32, 495 and personal communication.

(24) Pople, J. A.; Hehre, W. J.; Radom, L.; Schleyer, P. v. R. Ab-Initio Molecular Orbital Theory; Wiley: New York, 1986.

(25) Albright, T. A.; Burdett, J. K.; Whangbo, M. H. Orbital Interaction in Chemistry; Wiley: New York, 1985.

(26) Randall, S. L.; Thompson, J.S.; Buttrey, L. A.; Ziller, J. W.; Churchill, M. R.; Atwood, J. D. Organometallics 1991, 10, 683.

(27) Crabtree, R. H.; Holt, E. M.; Lavin, M.; Morehouse, S. M. Inorg. Chem. 1985, 24, 1986.

(28) Neve, F.; Ghedini, M.; De Munno, G.; Crispini, A. Organometallics 1991, 10, 1143. 
to a vinyl; hydrocarbyls are known to have large trans influences. ${ }^{29}$ $\mathrm{Ir}-\mathrm{Cl}$ bond lengths in $\mathrm{Ir}(\mathrm{H})(\mathrm{Cl})\left(\mathrm{PPh}_{3}\right)_{2}\left(\eta^{3}-\mathrm{C}_{3} \mathrm{H}_{4} \mathrm{Ph}\right),{ }^{30} \mathrm{Ir}(\mathrm{H})_{2}$ $(\mathrm{Cl})\left(\mathrm{Ph}_{2} \mathrm{P}\left(\mathrm{CH}_{2}\right)_{2} \mathrm{CH}=\mathrm{CH}\left(\mathrm{CH}_{2}\right)_{2} \mathrm{PPh}_{2}\right),{ }^{31}$ and $\mathrm{Ir}(\mathrm{Cl})\left(\mathrm{Ph}_{2} \mathrm{P}-\right.$ $\left.\left(\mathrm{CH}_{2}\right)_{2} \mathrm{CH}=\mathrm{CH}\left(\mathrm{CH}_{2}\right)_{2} \mathrm{PPh}_{2}\right)^{31}$ are 2.549(2), 2.510(5), and $2.391(2) \AA$, respectively. The $\mathrm{Ir}-\mathrm{Cl}$ bond length in $1 \mathrm{~b}$ is somewhat shorter than that in experimental models, as one might anticipate given its low coordination number and lack of a trans ligand. Teller and $\mathrm{Bau}^{32}$ quote an average $\mathrm{Ir}-\mathrm{H}$ bond length of $1.67 \pm$ $0.07 \AA$ for Ir-H bonds with a range $1.57(7)-1.82(17) \AA$. The sum of the single-bond metallic radius of $\operatorname{Ir}(1.27 \AA)$ and the covalent radius of $\mathrm{H}(0.37 \AA$ or half the equilibrium bond length of $\mathrm{H}_{2}$ ) is $1.64 \AA .^{33}$ Three iridium hydride complexes have been characterized by neutron diffraction: $\mathrm{Ir}-\mathrm{H}=1.603(9) \AA$ (average $\mathrm{Ir}-\mathrm{H}$ in $\left.\operatorname{Ir}(\mathrm{H})_{5}\left(\mathrm{P}-i-\mathrm{Pr}_{3}\right)_{2}\right), 1.59 \AA\left(\left[\mathrm{H}_{4} \operatorname{IrPt}\left(\mathrm{PEt}_{3}\right)_{4}\right]^{+}\right)$, and $1.594(3) \AA\left(\mathrm{H}_{2} \mathrm{Ir}\left(\mathrm{SiEt}_{3}\right)_{2} \mathrm{Cp}^{*}\right),{ }^{34}$ all in good agreement with the calculated value of $\mathrm{Ir}-\mathrm{H}$ in 1a. Thus, calculated $\mathrm{Ir}-\mathrm{X}$ bonds in model reactants (1) are in accord with experimental data. Good agreement between theory and experiment has been found in previous work ${ }^{18}$ using ECPs and valence basis sets; ${ }^{20 \mathrm{a}}$ it is satisfying to find this trend continued for a new family of low-valent TM complexes.

2. Initial Interaction of Substrate and Reactant Complex. Substantial interest has focused on loosely bound, alkane adducts of TM complexes and their relevance to alkane activation. ${ }^{35-43}$ For silanes, $\eta^{2}$-SiH adducts are stable enough to permit structural analysis. ${ }^{41}$ Parkin and Bercaw ${ }^{42}$ have measured inverse kinetic isotope effects for methane elimination from $\mathrm{Cp}^{*}{ }_{2} \mathrm{~W}\left(\mathrm{CH}_{3}\right)(\mathrm{H})$ and deuterated isotopomers, as have Gould and Heinekey ${ }^{43}$ for $\left[\mathrm{Cp}_{2} \mathrm{Re}(\mathrm{H})\left(\mathrm{CH}_{3}\right)\right]^{+}$. Both findings have been interpreted in terms of adduct formation. Bergman et al. ${ }^{35}$ have used time-resolved infrared spectroscopy (TRIS) to probe alkane adducts of $\mathrm{CpRh}(\mathrm{CO})$. Rayner et al. have performed gas-phase TRIS studies of alkane interaction with $\mathrm{W}(\mathrm{CO})_{5 \cdot{ }^{36}}$ Burkey $^{37}$ has used photoacoustic calorimetry to measure enthalpies of adduct formation between hydrocarbons and coordinatively unsaturated species such as $\mathrm{M}(\mathrm{CO})_{5}(\mathrm{M}=\mathrm{Cr}, \mathrm{Mo}, \mathrm{W})$. Thus, there is a growing body of kinetic, spectroscopic, and thermochemical data supporting the presence of alkane adducts of TM complexes. The structure of these transients and their function, if any, in the crucial bond scission step are less clear.

On the basis of TRIS studies, an adduct-binding enthalpy $\left(\Delta H_{\text {add }}\right)$ of $10 \mathrm{kcal} \mathrm{mol}^{-1}$ has been estimated for alkanes and $\mathrm{CpRh}(\mathrm{CO}){ }^{35}$ Burkey has measured $\Delta H_{\text {add }}$ values as high as 17 $\mathrm{kcal} \mathrm{mol}^{-1}\left(\mathrm{Mo}(\mathrm{CO})_{5}+\right.$ heptane $)$ in solution. ${ }^{37}$ Gas-phase $\Delta \boldsymbol{H}_{\text {add }}$ values for $\mathrm{Cr}(\mathrm{CO})_{5}$ with alkanes and fluorinated alkanes range

(29) Cotton, F. A.; Wilkinson, G. Advanced Inorganic Chemistry, 5th ed.; Wiley: New York, 1991; p 1300

(30) Tulip, T. H.; Ibers, J. A. J. Am. Chem. Soc. 1978, 100, 3252. Tulip, T. H.; Ibers, J. A. J. Am. Chem. Soc. 1979, 101, 4201.

(31) Clark, G. R.; Mazid, M. A.; Russell, D. R.; Clark, D. R.; Jones, A. J. J. Organomet. Chem. 1979, 166, 109.

(32) Bau, R.; Teller, R. G. Stuct. Bondong (Berlin) 1981, 44, 1.

(33) Pauling, L. The Nature of the Chemical Bond, 3rd ed.; Cornell Press: Ithaca, NY, 1961.

(34) Garlaschelli, L.; Kahn, S. I.; Bau, R.; Longoni, G.; Koetzle, T. F. J. Am. Chem. Soc. 1985, 107, 7212.

(35) (a) Weiller, B. H.; Wasserman, E. P.; Bergman, R. G.; Moore, C. B.; Pimentel, G. C. J. Am. Chem. Soc. 1989, 111, 8288. (b) Wasserman, E. P.; Moore, C. B.; Bergman, R. G. Science 1992, 255, 315.

(36) Brown, C. E.; Ishikawa, Y.; Hackett, P. A.; Rayner, D. M. J. Am. Chem. Soc. 1990, 112, 2530.

(37) Burkey, T. J. In Energetics of Organometallic Species; Simoes, J. A. M., Ed.; Kluwer: Dordrecht, The Netherlands, 1992.

(38) Schaller, C. P.; Bennett, J. L.; Wolczanski, P. T. Abstracts of Papers, of the American Chemical Society, Washington, DC, Fall 1992; American Chemical Society: Washington, DC, 1992; INOR 453.

(39) Green, M. L. H.; Brookhart, M.; Wong, L. K. Prog. Inorg. Chem. $1988,36,1$.

(40) A computational study of methane adducts of high-valent, C-Hactivating complexes has been conducted. Cundari, T. R. Organometallics 1993, 12, 1998 .

(41) A review of $\sigma$-bonded $\mathrm{X}-\mathrm{H}$ complexes can be found in: Crabtree, $\mathrm{R}$.

H.; Hamilton, D. G. Adv. Organomet. Chem. 1988, 28, 299.

(42) Parkin, G.; Bercaw, J. E. Organometallics 1989, 8, 1172.

(43) Gould, G. L.; Heinekey, D. M. J. Am. Chem. Soc. 1989, 111, 5502.
Memphis State University

MOLPLT

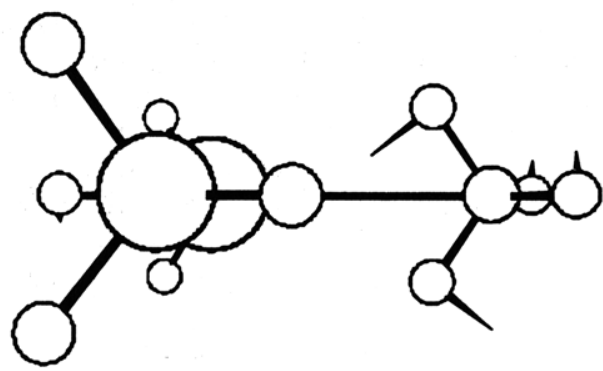

$\mathrm{Ir}(\mathrm{PH} 3) 2(\mathrm{H})+\mathrm{CH} 4$

$111.9 \mathrm{~cm}^{* *-1}$

Figure 1. Imaginary frequency for bifurcated $(\mathrm{H})\left(\mathrm{PH}_{3}\right)_{2} \mathrm{Ir} \cdots \mathrm{H}_{2} \mathrm{CH}_{2}$ adduct.

from $<5$ (methane) to $12.2 \mathrm{kcal} \mathrm{mol}^{-1}(\mathrm{EtF}) .^{36}$ Ziegler et al. calculate a linear geometry for $\mathrm{Cp}(\mathrm{L}) \mathrm{M} \cdot . \cdot \mathrm{HCH}_{3}(\mathrm{M}=\mathrm{Rh}$, Ir; $\mathrm{L}=\mathrm{PH}_{3}, \mathrm{CO}$ ); binding energies are $\approx 13 \mathrm{kcal} \mathrm{mol}^{-1}$ for $\mathrm{CpIr}(\mathrm{L})$ and 6-7 kcal mol-1 for $\mathrm{CpRh}(\mathrm{L}) .^{16}$ Blomberg et al. ${ }^{44}$ find a bifuracted $\mathrm{Rh} \cdots \mathrm{H}_{2} \mathrm{CH}_{2}$ adduct (binding energy $=8.5 \mathrm{kcal} \mathrm{mol}^{-1}$ ) lower in energy than a linear adduct by $3.4 \mathrm{kcal} \mathrm{mol}^{-1}$. Koga and Morokuma ${ }^{15}$ calculate a bifurcated $\left(\mathrm{PH}_{3}\right)_{2}(\mathrm{Cl}) \mathrm{Rh} \cdot \cdots \mathrm{H}_{2} \mathrm{CH}_{2}$ adduct as lowest in energy with many conformers close in energy. Calculated binding energies for $\left[(\mathrm{Cl})\left(\mathrm{PH}_{3}\right)_{2} \mathrm{Rh}\right] \ldots\left[\mathrm{CH}_{4}\right]$ range from -8.3 to $-17.7 \mathrm{kcal} \mathrm{mol}^{-1}$ depending on level of theory. ${ }^{15}$ Note that the calculated quantities are binding energies and not binding enthalpies (i.e., no correction for zero-point energy and a temperature above absolute zero). ${ }^{45}$ However, on the basis of our experience, binding enthalpies are higher (less negative) by only a few kcal mol-1 than binding energies.

Initial optimization of bifurcated $\operatorname{Ir}\left(\mathrm{PH}_{3}\right)_{2}(\mathrm{H}) \cdots \mathrm{H}_{2} \mathrm{CH}_{2}$ (2) was carried out in $\mathrm{C}_{2}$ symmetry. Calculation of the energy Hessian reveals a single imaginary frequency $\left(112 i \mathrm{~cm}^{-1}\right)$ for 2 , corresponding to the motion in Figure 1. Distorting along the imaginary

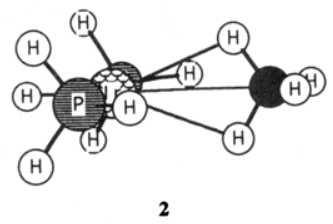

mode, followed by geometry optimization (in $C_{s}$ symmetry), yields a minimum (3a) lower than 2 by only $0.1 \mathrm{kcal} \mathrm{mol}^{-1}$ at the RHF
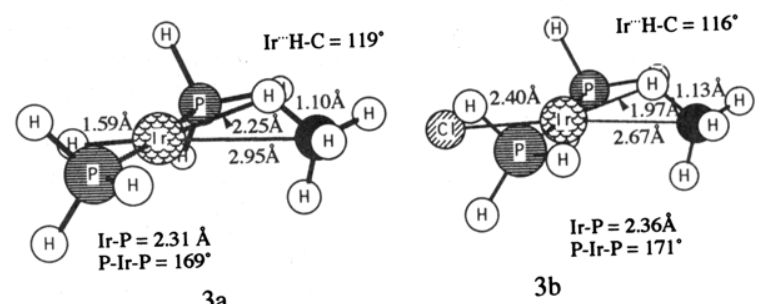

level. Thus, as Koga and Morokuma have clearly shown, 15 different adduct geometries can be very close in energy. Reducing optimization convergence criteria by an order of magnitude yields no significant change in geometry ( $\ll 1 \%$ changes in bond lengths and bond angles) or energy ( $<0.1$ mhartree). It seems likely that at ambient temperatures a methane adduct will be fluxional, sampling different coordination modes. Simple replacement of

(44) Blomberg, M. R. A.; Siegbahn, P. E. M.; Svensson, M. J. Phys. Chem. 1991, 95, 4313.

(45) Calculation of zero-point energies and the correction from $0 \mathrm{~K}$ to some finite temperature is done with the equations on p 259 of ref 24 using RHF vibrational frequencies. 
$\mathrm{H}$ with $\mathrm{Cl}$ yields an $\eta^{2}-\mathrm{CH}$ minimum $\left(C_{s}\right.$ symmetry, $\left.3 \mathrm{~b}\right)$ for which Ir...C and Ir...H distances are much shorter. The differences in calculated geometries are reflected in a greater $\Delta H_{\text {add }}$ for $\operatorname{Ir}\left(\mathrm{PH}_{3}\right)_{2}(\mathrm{Cl})$ versus $\operatorname{Ir}\left(\mathrm{PH}_{3}\right)_{2}(\mathrm{H})$. Calculated $\Delta H_{\text {add }}$ values for $3 \mathrm{a}$ and $3 \mathrm{~b}$ are -6.8 and $-15.6 \mathrm{kcal} \mathrm{mol}^{-1}$, respectively. ${ }^{46}$ Calculated values for $\Delta H_{\text {add }}$ are in line with the experimental and computational estimates given above; more quantitative assessments will require higher levels of theory.

Calculated intrinsic stretching frequencies ${ }^{47}$ show coordinated C-H bonds to be much weaker than spectator C-H bonds: 2873 $\mathrm{cm}^{-1}$ versus $3014 \pm 16 \mathrm{~cm}^{-1}$ (3a) and $2680 \mathrm{~cm}^{-1}$ versus 3032 $17 \mathrm{~cm}^{-1}(3 \mathrm{~b})$. Note that the coordinated $\mathrm{C}-\mathrm{H}$ is much weaker in $\mathbf{3 b}$ than in 3a, consistent with bond lengths of the coordinated $\mathrm{C}-\mathrm{H}: 1.10 \AA$ in $3 \mathrm{a} ; 1.13 \AA$ in $\mathbf{3 b}$. The charge on the methane fragment (from Mulliken population analyses) in $3 \mathrm{a}$ is +0.14 versus +0.25 for $\mathbf{3 b}$. Within the Saillard-Hoffmann ${ }^{13}$ model two explanations seem feasible for the difference in charges. Replacement of $\mathbf{X}=\mathrm{H}$ with $\mathbf{X}=\mathrm{Cl}$ makes $\mathbf{1 b}$ a better acceptor for $\sigma_{\mathrm{CH}}$ than $1 \mathbf{a} ; \mathbf{1 b}$ is less effective at $\pi$-backbonding to $\sigma^{*}{ }_{\mathrm{CH}}$ than 1a. The Mulliken charge on Ir is -1.10 in $1 \mathrm{a}$ and -0.69 for 1b. A less negative charge on 1b should lower in energy metalbased MOs (as the calculations indicate); however, $\pi$-donation from the chloro destabilizes the $\mathrm{d} \pi$ orbital perpendicular to the $\mathrm{IrP}_{2} \mathrm{X}$ plane (the one backbonding to $\sigma^{*} \mathrm{CH}$ ), making it roughly the same energy in $1 \mathrm{a}(-0.314$ hartree $)$ and $\mathbf{1 b}(-0.324$ hartree $)$. The calculations thus point to $1 \mathrm{a}$ and $\mathbf{1 b}$ being equivalent $\pi$-donors with the latter a better $\sigma$-acceptor, leading to a more exothermic $\Delta H_{\text {add }}$ and increased $\mathrm{C}-\mathrm{H}$ weakening upon adduct formation for 3b. The weakening of coordinated $\mathrm{C}-\mathrm{H}$ which occurs upon adduct formation may assist in $\mathrm{C}-\mathrm{H}$ scission, as suggested for intermolecular ${ }^{41}$ and intramolecular ${ }^{39,48} \mathrm{M} \cdot . \mathrm{H}-\mathrm{C}$ complexes. The calculations show the adduct to be sensitive to electronic effects induced by ancillary ligands, in addition to steric factors. ${ }^{15,17 b, 36}$ Tunable properties are attractive from the standpoint of designing a catalyst precursor in which $\mathrm{C}-\mathrm{H}$ bond weakening is maximized in an adduct, particularly if the interactions carry through to the transition state and lower the activation barrier.

3. Products. Products are 16-electron, five-coordinate $\mathrm{Ir}^{\mathrm{III}}$ complexes- $\operatorname{Ir}(\mathrm{X})(\mathrm{H})\left(\mathrm{CH}_{3}\right)\left(\mathrm{PH}_{3}\right)_{2}(4)$. The phosphines remain trans to each other with angles close to $180^{\circ}$. The geometry of the complexes is closer to a square pyramid (SQP5) than a trigonal bipyramid (TBP5). Frontier orbital arguments suggest that a $\mathrm{d}^{6}$ TBP5 complex will be Jahn-Teller unstable and distort to an SQP5 geometry; ${ }^{25}$ furthermore, a Walsh diagram shows the preferred $\mathrm{L}_{\text {apical }}-\mathrm{M}-\mathrm{L}_{\text {basal }}$ angle to be near $90^{\circ} .{ }^{25}$ The optimized geometries of the products (4) bear out these predictions in all respects.

The $\mathrm{Ir}-\mathrm{X}$ bonds $\mathrm{X}=\mathrm{H}, \mathrm{Cl}, \mathrm{P}$ ) are in good agreement with experimental models described above. The most interesting changes in bond lengths highlight the trans influence of hydrido and methyl ligands. The $\mathrm{Ir}-\mathrm{Cl}$ bond in $\mathbf{4 b}$, trans to methyl, lengthens by $0.12 \AA$ (versus $1 \mathrm{~b}$ ); the $\mathrm{Ir}-\mathrm{H}$ bond in $\mathbf{4 a}$, trans to a methyl, lengthens by $0.10 \AA$, still within reported limits. ${ }^{32}$ Rausch et al. ${ }^{49}$ quote $\mathrm{Ir}-\mathrm{C}$ distances ranging from $1.982(26)$ to $2.202(4)$ $\AA$ depending on metal coordination environment. The Ir-C

(46) Modification of ancillary ligands can substantially affect the acidity/ basicity of a metal center. Replacement of hydride with chloride makes the Os center significantly more acidic/less basic in $\mathrm{CpOs}\left(\mathrm{PPh}_{3}\right)_{2} \mathrm{X}$. The enthalpy of protonation by $\mathrm{CF}_{3} \mathrm{SO}_{3} \mathrm{H}$ is $23.2 \mathrm{kcal} \mathrm{mol}^{-1}$ less exothermic for CpOs $\left(\mathrm{PPh}_{3}\right)_{2} \mathrm{Cl}$ than $\mathrm{CpOs}\left(\mathrm{PPh}_{3}\right)_{2} \mathrm{H}$. Rottink, M. K.; Angelici, R. J. J. Am. Chem. Soc. 1992, 114, 8296.

(47) (a) Boatz, J. A.; Gordon, M. S. J. Phys. Chem. 1989, 93, 1819. (b) Calculated stretching frequencies are typically $10 \%$ too high and thus scaled by 0.9 to account for correlation and anharmonicity. Pople, J. A.; Schlegel, H. B.; Krishnan, R.; DeFrees, D. F.; Binkley, J. S.; Frisch, M. J.; Whiteside, R.; Hout, R. F.; Hehre, W. J. Int. J. Quantum Chem., Proc. Sanibel Symp. $1981,15,269$. We have used a scaling factor of 0.925 , since this best reproduces the experimental C-H stretches of methane.

(48) (a) Crabtree, R. H. Chem. Rev. 1985, 85, 245. (b) Schrock, R. R. Acc. Chem. Res. 1979, 12, 98.

(49) Rausch, M. D.; Clearfield, A.; Gopal, R.; Bernal, I.; Moser, G. A. Inorg. Chem. 1975, 11, 2727.

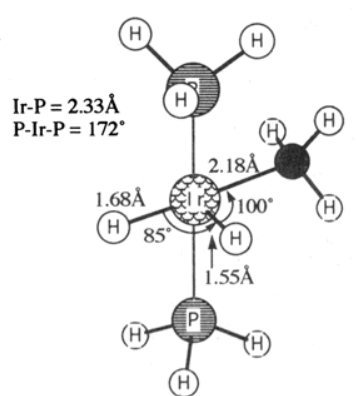

$4 \mathrm{a}$

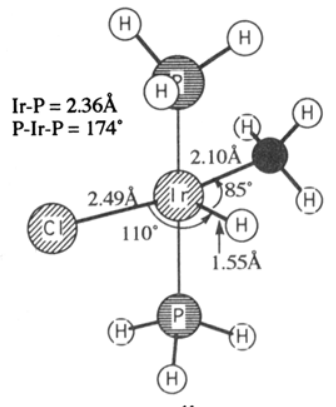

$4 \mathrm{~b}$ distance in the complex with a trans hydrido $(\mathrm{Ir}-\mathrm{C}=2.18 \AA, 4 \mathrm{a})$ is much longer than that with a trans chloro $(\mathrm{Ir}-\mathrm{C}=2.10 \AA, \mathbf{4 b})$, in line with the trans influence order $\mathrm{H}^{-}>\mathrm{CH}_{3}{ }^{-}>\mathrm{Cl}^{-} .{ }^{29}$ Apical $\mathrm{H}$ atoms in $\mathbf{4 a}$ and $\mathbf{4 b}$ are trans to a vacant coordination site and show $\mathrm{Ir}-\mathrm{H}$ bond lengths $(1.55 \AA)$ nearly identical to that of the $\operatorname{Ir}\left(\mathrm{PH}_{3}\right)_{2}(\mathrm{H})$ reactant $(1.58 \AA)$.

The $\operatorname{Ir}\left(\mathrm{PH}_{3}\right)_{2}(\mathrm{H})+\mathrm{CH}_{4} \rightarrow \operatorname{Ir}\left(\mathrm{PH}_{3}\right)_{2}(\mathrm{H})_{2}(\mathrm{Me})$ reaction enthalpy is $-12.8 \mathrm{kcal} \mathrm{mol}^{-1}$ versus separated reactants, while that for $\operatorname{Ir}\left(\mathrm{PH}_{3}\right)_{2}(\mathrm{Cl})$ is $-41.6 \mathrm{kcal} \mathrm{mol}^{-1}$. Theoretical estimates for methane $\mathrm{C}-\mathrm{H}$ oxidative addition are $-15,-17,-33$, and -36 kcal mol ${ }^{-1}$ for $\mathrm{CpRh}(\mathrm{CO}), \mathrm{CpRh}\left(\mathrm{PH}_{3}\right), \mathrm{CpIr}(\mathrm{CO})$, and $\mathrm{CpIr}-$ $\left(\mathrm{PH}_{3}\right)$, respectively. ${ }^{16} \mathrm{Koga}$ and Morokuma ${ }^{15}$ calculate reaction energies for $(\mathrm{Cl})\left(\mathrm{PH}_{3}\right)_{2}+\mathrm{CH}_{4} \rightarrow \mathrm{Rh}(\mathrm{Cl})(\mathrm{H})\left(\mathrm{CH}_{3}\right)\left(\mathrm{PH}_{3}\right)_{2}$ from -17.3 to $-24.4 \mathrm{kcal} \mathrm{mol}^{-1}$. Experimental $\mathrm{Ir}-\mathrm{H}$ and $\mathrm{Ir}-\mathrm{R}$ bond strengths for $C p^{*} \operatorname{Ir}(R)_{2}$ are 74 and $56 \mathrm{kcal} \mathrm{mol}^{-1}(\mathrm{R}=\mathrm{Me}) .^{50}$ Combining these values with a methane $\mathrm{C}-\mathrm{H}$ bond strength of $105 \mathrm{kcal} \mathrm{mol}^{-1}$ yields an estimate of $-25 \mathrm{kcal} \mathrm{mol}^{-1}$ for $\mathrm{Cp} * \operatorname{Ir}\left(\mathrm{PMe}_{3}\right)+\mathrm{H}_{3} \mathrm{C}-\mathrm{H} \rightarrow \mathrm{Cp} * \operatorname{Ir}\left(\mathrm{PMe}_{3}\right)(\mathrm{H})\left(\mathrm{CH}_{3}\right) .^{51} \mathrm{Ir}-\mathrm{C}$ bond enthalpies in $\operatorname{Ir}(\mathrm{Cl})_{2}(\mathrm{CO})\left(\mathrm{PR}_{3}\right)_{2}(\mathrm{C}(\mathrm{O}) \mathrm{Me})$ span a range of 12 kcal mol-1 for a variety of $\mathrm{PR}_{3}$ ligands; ${ }^{52} \mathrm{Ir}-\mathrm{C}$ bond energies in $\mathrm{Ir}(\mathrm{Cl})_{2}(\mathrm{CO})\left(\mathrm{PPh}_{3}\right)(\mathrm{R})$ are spread over a $17 \mathrm{kcal} \mathrm{mol}^{-1}$ range depending on the nature of $\mathrm{R} .{ }^{53}$ Bond strengths of $\mathrm{Ir}-\mathrm{C}$ are thus very sensitive to the chemical environment, a contention further supported by the large range of $\mathrm{Ir}-\mathrm{C}$ bond lengths quoted by Rausch et al. ${ }^{49}$ The stronger trans influence of hydrido versus chloro leads one to predict that the $\mathrm{Ir}-\mathrm{C}$ bond will be weaker in $4 a$ than in $4 b$; thus, reaction 2 will be more exothermic for $X=$ $\mathrm{Cl}$ than for $\mathrm{X}=\mathrm{H}$, as found. The calculations suggest that the relative trans influence of hydride versus chloride is great enough to lead to a large difference in reaction exothermicities. Detailed studies of transition metal-carbon bond enthalpies as a function of trans ligand would be of great value in this regard.

4. Transition State. It is generally agreed ${ }^{5,11,14,54}$ that lowvalent complexes activate $\mathrm{C}-\mathrm{H}$ bonds through a triangular M-H-C oxidative addition transition state (TS), 5a. The

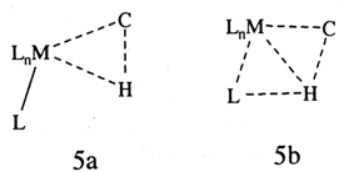

oxidative addition TS is quite distinct from the four-centered, $\sigma$-bond metathesis TS, 5 b. ${ }^{6}$ Stationary points (6) with the geometry shown in $5 \mathrm{a}$ are found. That $6 \mathrm{a}$ and $\mathbf{6 b}$ are transition states at this level of theory is confirmed by calculation of the

(50) Stoutland, P. O.; Bergman, R. G.; Nolan, S. P.; Hoff, C. D. Polyhedron 1988, 7, 1429.

(51) Crabtree 11 has proposed that $\mathrm{C}-\mathrm{H}$ activation by 16-electron $\mathrm{Cp} * \mathrm{M}\left(\mathrm{PR}_{3}\right)(\mathrm{M}=\mathrm{Ir}, \mathrm{Rh})$ species will have greater thermodynamic driving force versus that by 14-electron $(X) \operatorname{Ir}\left(P_{3}\right)_{2}$, because the former $d^{8}$ complex is forced into a nonplanar arrangement by $\mathrm{Cp}^{*}$.

(52) Simoes, J. A. M.; Beauchamp, J. L. Chem. Rev. 1990, 90, 629.

(53) Blake, D. M.; Winkelman, A.; Chung, Y. L. Inorg. Chem. 1975, 14, 1326.

(54) Rest et al. have proposed that the 16-electron $\mathrm{C}-\mathrm{H}$-activating species produced upon photolysis of $\mathrm{CpIr}(\mathrm{CO})_{2}$ is not $\mathrm{CpIr}(\mathrm{CO})$ but rather $\eta^{3}-\mathrm{CpIr}(\mathrm{CO})_{2}$. Oxidative addition is still the preferred pathway for $\mathrm{C}-\mathrm{H}$ activation. Rest, A. J.; Whitewell, I.; Graham, W. A. G.; Hopkins, J. K.; McMaster, A. D. J. Chem. Soc., Chem. Commun. 1984, 824. 


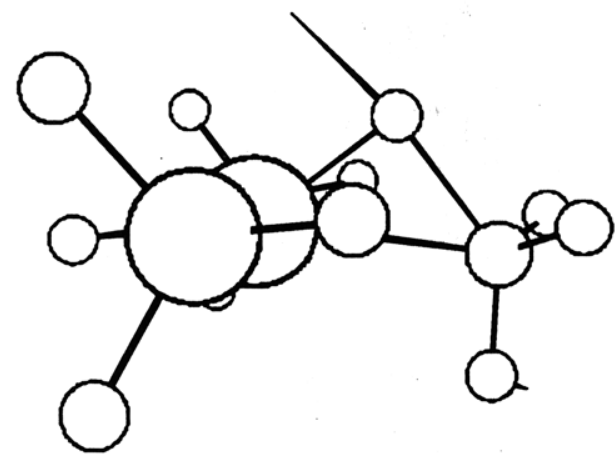

$\operatorname{Ir}(\mathrm{PH} 3) 2(\mathrm{H}) 2(\mathrm{Me})$ : $\mathrm{TS}$ for $\mathrm{OA}$

$1168.1 \mathrm{~cm}^{* *}-1$

Figure 2. Imaginary frequency for TS of oxidative addition of methane to $\operatorname{Ir}\left(\mathrm{PH}_{3}\right)_{2}(\mathrm{H})$.

energy Hessian which shows only one imaginary vibrational frequency: $1168 i \mathrm{~cm}^{-1}$ (for 6a) and $1124 i \mathrm{~cm}^{-1}$ (for 6b), respectively (see Figure 2 for the hydrido model; the chloro analogue is identical). Decomposition of the imaginary mode into internal coordinate displacements shows the major component to be $\mathrm{C}-\mathrm{H}$ bond breaking (formation for the reverse), as one would expect for a true oxidative addition TS (Figure 2).

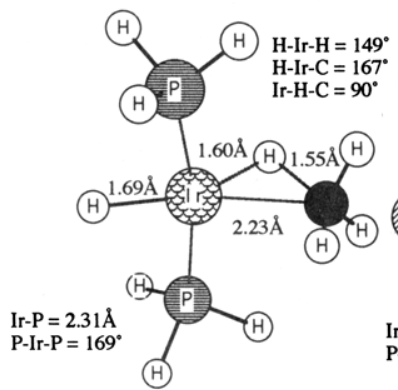

$6 a$

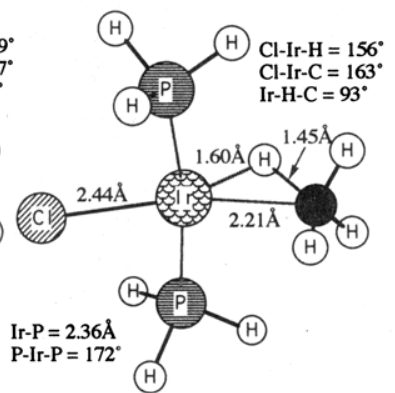

$6 b$
Activation barriers change dramatically upon the inclusion of electron correlation. Enthalpies of activation for $3 a \rightarrow 6 a$ and $3 \mathbf{b} \rightarrow 6 \mathbf{b}$ are 20 and $9 \mathrm{kcal} \mathrm{mol}^{-1}$, respectively, at the RHF level. Calculation of energies at the MP2 level (using RHF-optimized geometries) lowers barriers by $19 \mathrm{kcal} \mathrm{mol}^{-1}$ for both cases, yielding a negative calculated barrier for $\mathrm{X}=\mathrm{Cl}$. For the $\mathrm{Rh}(\mathrm{Cl})\left(\mathrm{PH}_{3}\right)_{2}$ $+\mathrm{CH}_{4} \rightarrow \mathrm{Rh}(\mathrm{Cl})\left(\mathrm{PH}_{3}\right)_{2}\left(\mathrm{CH}_{3}\right)(\mathrm{H})$ reaction, methane activation barriers range from -2.3 to $7.7 \mathrm{kcal} \mathrm{mol}^{-1}$, compared with barriers of $15-24 \mathrm{kcal} \mathrm{mol}^{-1}$ (depending on basis set size) at the RHF level. ${ }^{15}$ These changes in activation barrier might suggest that a single-determinant description of the TS is not sufficient. However, a multiconfiguration self-consistent field (MCSCF) calculation $^{55}$ at the RHF transition state shows a very large contribution $(>95 \%)$ from the Hartree-Fock configuration, as found for $\mathrm{d}^{0}$ methane activators. ${ }^{18 \mathrm{a}-\mathrm{c}}$ Probing the complete reaction coordinate for oxidative addition at correlated levels would be of interest, although computationally expensive. Experiments indicate that $\mathrm{C}-\mathrm{H}$ oxidative addition to low-valent metals proceeds with small activation barriers (Bergman et al. ${ }^{35 \mathrm{~b}}$ estimate a barrier of only $5 \mathrm{kcal} \mathrm{mol}^{-1}$ ), as found in this and previous ${ }^{15-17,44}$ theoretical studies.

(55) The two MOs located on the Ir...H...C "active site" are included in the MCSCF active space as are their antibonding counterparts. This yields a four-orbital/four-electron active space. The FORS (full optimized reaction space)-MCSCF wave function is generated by constructing all possible singlet configurations (20 in total). Schmidt, M. W.; Ruedenberg, K.; Elbert, S. T.; Gilbert, M. M. Chem. Phys. 1982, 92, 1476.
The most interesting point to emerge from calculation of TS geometries is the extent to which $\mathrm{Ir}-\mathrm{H}$ and $\mathrm{Ir}-\mathrm{C}$ bond lengths are formed in the transition state. Relative to their values in the product, the $\mathrm{Ir}-\mathrm{C}$ and $\mathrm{Ir}-\mathrm{H}$ bond lengths in TS $6 \mathrm{a}$ ( 2.23 and 1.60 $\AA$, respectively) are only $2 \%$ and $3 \%$ longer than those in product 4a; for the chloro derivative, Ir-C and Ir-H bond lengths in TS 4b (2.21 and $1.60 \AA$, respectively) are $6 \%$ and $3 \%$, respectively, longer than those in product $\mathbf{4 b}$. The $\mathrm{C}-\mathrm{H}$ bond being activated is further removed from equilibrium values than $\mathrm{Ir}-\mathrm{H}$ and $\mathrm{Ir}-\mathrm{C}$ : $+55 \%$ (6a) and $+31 \%(6 \mathrm{~b})$. Crabtree ${ }^{11}$ has deduced a late TS for oxidative addition in 14-electron complexes on the basis of selectivity patterns; kinetic products arise from activation at the least hindered $\mathrm{C}-\mathrm{H}$ bonds in the substrate, suggesting a short $\mathrm{M}-\mathrm{C}$ distance in the TS and steric hindrance between substituents on $\mathrm{C}$ and ancillary ligands. The calculations support a "late" transition state for oxidative addition; not only is the $\mathrm{Ir}-\mathrm{C}$ interaction substantial but $\mathrm{Ir}-\mathrm{H}$ is as well. The tightness of transition states $\mathbf{6 a}$ and $\mathbf{6 b}$ should make it profitable to control the selectivity of alkane functionalization catalysts built around these 14-electron $\mathrm{X}(\mathrm{M})\left(\mathrm{PR}_{3}\right)_{2}$ species, particularly through choice of $R$ groups on the phosphines. ${ }^{56}$

5. Intrinsic Reaction Coordinate. The intrinsic reaction coordinate (IRC) ${ }^{21}$ yields dynamic information about chemical interactions which dictate the ease of passage of reactants through the TS and on to products. Crabtree et al. ${ }^{27}$ have analyzed the crystal structures of agostic complexes and thus constructed a trajectory for $\mathrm{C}-\mathrm{H}$ oxidative addition. This experimental trajectory is then used to follow the evolution of the $\mathrm{C}-\mathrm{H}$ distance and $\mathrm{M} \cdots \mathrm{H} \cdots \mathrm{C}$ angle for the $\mathrm{C}-\mathrm{H}$ being oxidatively added. Since the IRC is mathematically defined as the steepest descent path (in mass-weighted Cartesian coordinates) from the TS to reactants and products, it can also be calculated from first-principles quantum mechanics, ${ }^{21}$ making it of interest to compare the wellknown experimental trajectory ${ }^{27}$ with a computational trajectory.

Calculated changes in bond lengths and angles along the IRC for $\left(\mathrm{PH}_{3}\right)_{2}(\mathrm{H}) \mathrm{Ir} \cdots \mathrm{H}_{2} \mathrm{CH}_{2} \rightarrow[\ddagger] \rightarrow \operatorname{Ir}\left(\mathrm{PH}_{3}\right)_{2}(\mathrm{H})_{2}\left(\mathrm{CH}_{3}\right)(3 \mathrm{a} \rightarrow$ $6 \mathbf{a} \rightarrow \mathbf{4 a})$ are shown in Figure 3a using the reaction coordinate $\left(r_{\text {bp }}\right.$, eqs 3 and 4$)$ defined by Crabtree et al. ${ }^{27}(r=0.28 \AA ; 1.27$

$$
\begin{gathered}
d_{\mathrm{bp}}=\left[d_{\mathrm{MH}}{ }^{2}+r^{2} d_{\mathrm{CH}}{ }^{2}-r\left(d_{\mathrm{MH}}{ }^{2}+d_{\mathrm{CH}}{ }^{2}-d_{\mathrm{MC}}{ }^{2}\right)\right]^{1 / 2} \\
r_{\mathrm{bp}}=d_{\mathrm{bp}}-1.27 \AA
\end{gathered}
$$

$\AA$ is the covalent radius of $\mathrm{Ir}, r_{\mathrm{bp}}$ "is effectively the covalent radius of the $\mathrm{C}-\mathrm{H}$ bonding electrons."). ${ }^{27}$ In Figure $3 \mathrm{~b}$ the same bond length and bond angles are plotted using $S_{\text {total }}$ (eq 5), the

$$
\begin{aligned}
S_{\text {total }}=\sum_{i}\left[\left(x_{i}(0)-x_{i}(s)\right)^{2}+\left(y_{i}(0)-\right.\right. & \left.y_{i}(s)\right)^{2}+ \\
& \left.\left(z_{i}(0)-z_{i}(\mathrm{~s})\right)^{2}\right]^{1 / 2}
\end{aligned}
$$

mass distance along the reaction coordinate, on the abscissa. The values $x_{i}(0), y_{i}(0)$, and $z_{i}(0)$ in eq 5 are the mass-weighted Cartesian coordinates of atom $i$ at the TS, while $x_{i}(s), y_{i}(s)$, and $z_{i}(s)$ are the mass-weighted Cartesian coordinates of atom $i$ at a subsequent point along the IRC. Proceeding from positive to negative values of $S_{\text {total }}$ (Figure 3b) describes the oxidative addition process, the TS of which is at $S_{\text {total }}=0 \mathrm{bohr} \mathrm{amu}^{1 / 2}$. Inspection of Figure 3 shows that using either $r_{\text {bp }}$ or $S_{\text {total }}$ as the reaction coordinate yields nearly identical results for describing the $\mathrm{C}-\mathrm{H}$ oxidative addition trajectory. Thus, $S_{\text {total }}$ will be used as the reaction coordinate in subsequent discussion.

The experimental trajectory ${ }^{27}$ derived by Crabtree and coworkers is reproduced in Figure 4. It seems reasonable to ascribe

(56) Product selectivity for C-H activation by 16-electron CpML intermediates is kinetically controlled at low temperatures (where the reverse reaction, reductive elimination of hydrocarbons, is minimal) and thermodynamically controlled as one approaches room temperature. Jones, W. D. (Chemistry, Rochester). Personal communication. 


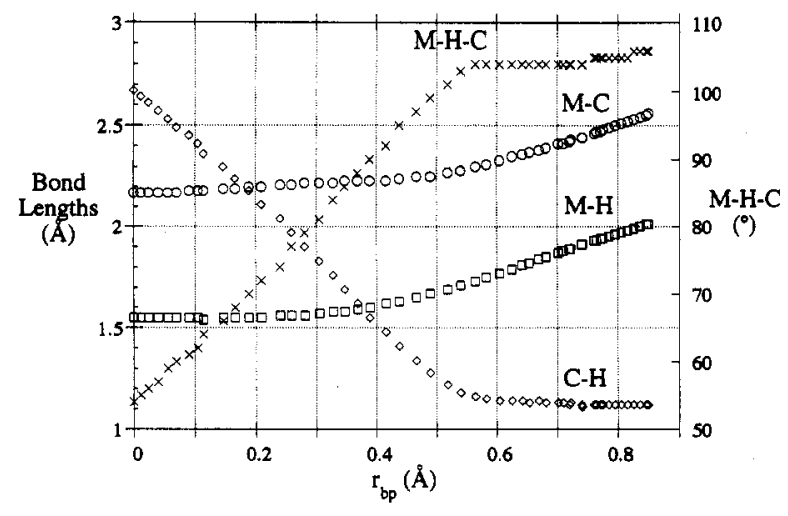

$(\mathrm{H})\left(\mathrm{PH}_{3}\right)_{2} \mathrm{Ir} \cdots \mathrm{HCH}_{3} \cdots\left(\mathrm{H}_{2}\left(\mathrm{PH}_{3}\right)_{2} \operatorname{Ir}\left(\mathrm{CH}_{3}\right)\right.$

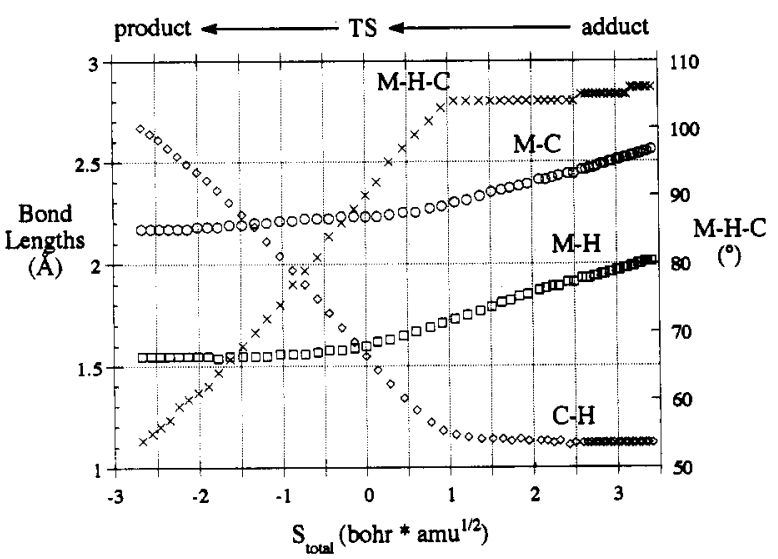

Figure 3. (a, top) Calculated bond length and bond angle changes along the IRC for conversion of the $\operatorname{Ir}\left(\mathrm{PH}_{3}\right)_{2}(\mathrm{H})\left(\eta^{2}-\mathrm{HCH}_{3}\right)$ adduct into $\operatorname{Ir}\left(\mathrm{PH}_{3}\right)_{2}\left(\mathrm{H}_{2}\left(\mathrm{CH}_{3}\right)\right.$ using $r_{b p}$ as the reaction coordinate. See text for definition of $r_{\mathrm{bp}}$. (b, bottom) Calculated bond length and bond angle changes along the IRC for conversion of the $\operatorname{Ir}\left(\mathrm{PH}_{3}\right)_{2}(\mathrm{H})\left(\eta^{2}-\mathrm{HCH}_{3}\right)$ adduct into $\operatorname{Ir}\left(\mathrm{PH}_{3}\right)_{2}(\mathrm{H})_{2}\left(\mathrm{CH}_{3}\right)$ using $S_{\text {total }}$ as the reaction coordinate. See text for definition of $S_{\text {total }}$.

differences with computed ones to the fact that the experimental trajectory is derived from consideration of a variety of complexes (with intramolecular M...H-C interaction) while the computational geometry arises from a single set of reactants (with intermolecular M...H-C interaction). However, the fact remains that similar behavior for the $\mathrm{C}-\mathrm{H}$ distance and $\mathrm{M}-\mathrm{H}-\mathrm{C}$ angle is exhibited in both experimental (Figure 4) and computational trajectories (Figure 3), which is pleasing given the important contribution the Crabtree trajectory has made to the thinking on $\mathrm{C}-\mathrm{H}$ activation. The computational trajectory does have an advantage in that it allows one to see important parts of the reaction coordinate not sampled by crystal structures, particularly in the region of the transition state.

Analysis of the changes in bond lengths and bond angles along the intrinsic reaction coordinate (Figure $3 b$ ) reveals three main points of interest.

(1) The Ir-H-C angle is nearly constant at $105^{\circ}$ for $S_{\text {total }} \geq$ $1 \mathrm{bohr} \mathrm{amu}^{1 / 2}$. The value obtained from the experimental reaction coordinate is $\approx 130^{\circ}$. The experimental trajectory ${ }^{27}$ was constructed from intramolecular, agostic complexes whose ability to sample the entire $\mathrm{M} \cdot \cdots \mathrm{H}-\mathrm{C}$ conformational space is more restricted than in an intermolecular case. The near degeneracy of the edgecoordinated (2) and $\eta^{2}-\mathrm{CH}(3 \mathrm{a})$ adducts for $\operatorname{Ir}\left(\mathrm{PH}_{3}\right)_{2}(\mathrm{H})\left(\mathrm{CH}_{4}\right)$ suggests that distortion along the $\mathrm{Ir}-\mathrm{H}-\mathrm{C}$ mode is very soft at this stage in the reaction. Steric hindrance is expected to be less in a linear adduct than for an $\eta^{2} \cdot \mathrm{CH}$ coordination geometry. However, an off-axis approach in the experimental and computational trajectories is consistent with a favorable orientation for donation from $\sigma_{\mathrm{CH}}$ to a vacant metal orbital concomitant with

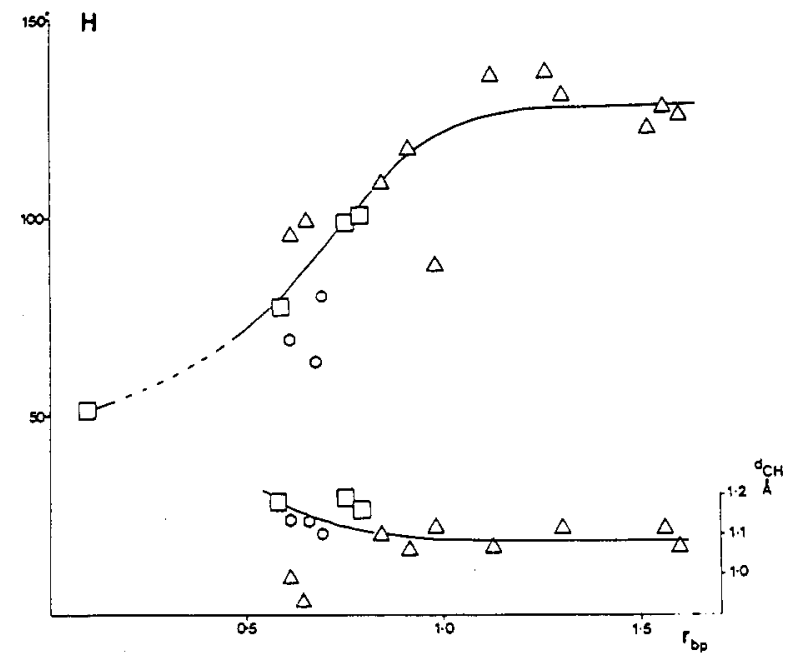

Figure 4. Plot of both $H$ (the angle $\mathrm{C}-\mathrm{H}-\mathrm{M}$ in deg) and $d_{\mathrm{CH}}(\AA)$ against $r_{\text {bp }}(\AA)$ from Table IV. Squares and hexagons refer to neutron data, triangles and circles to X-ray data. Hexagons and circles refer to $\alpha \cdot \mathrm{CH}$ bridges that are more constrained geometrically than $\beta$ and higher types (squares and triangles); more weight is attached to the latter, particularly with regard to $H$. Only when $r_{\text {bp }}$ falls appreciably below 1.0 does $H$ fall below $130^{\circ}$ and $d_{\mathrm{CH}}$ rise significantly above the value in the free $\mathrm{C}-\mathrm{H}$ bond (ca. $1.08 \AA$ ). The calculated value of $H$ for a cis alkyl hydride complex (entry 21 of Table IV) is also included; the corresponding value of $d_{\mathrm{CH}}(2.68 \AA)$ is too large to include in this plot. Figure 4 was reproduced with permission from the ACS and is taken from ref 27.

backdonation from a filled metal orbital into $\sigma^{*} \mathrm{CH}$; a linear (Ir$\mathrm{H}-\mathrm{C}=180^{\circ}$ ) approach does not allow for any backdonation.

(2) The $\mathrm{Ir}-\mathrm{H}$ and $\mathrm{Ir}-\mathrm{C}$ distances are nearly at the values they assume in the oxidative addition product even before the $\mathrm{C}-\mathrm{H}$ bond has begun to be activated (at $S_{\text {total }} \approx 1$ bohr amu ${ }^{1 / 2}$, Figure $3 \mathrm{~b})$. Thus, the main motion, and energetic expenditure, in the region of the transition state $\left(S_{\text {total }}=-1\right.$ bohr amu ${ }^{1 / 2}$ to $S_{\text {total }}=$ +1 bohr amu ${ }^{1 / 2}$, Figure $3 \mathrm{~b}$ ) corresponds to cleavage of the $\mathrm{C}-\mathrm{H}$ bond, as decomposition ${ }^{47 a}$ of the imaginary frequency (Figure 2) indicates. ${ }^{57}$ As mentioned above, a TS for $\mathrm{C}-\mathrm{H}$ activation with substantial $\mathrm{M}$... $\mathrm{C}$ bond formation has been inferred from selectivity patterns. ${ }^{11}$ Analysis of the IRC indicates that M...C (and $\mathrm{M} \cdots \mathrm{H}$ ) bond formation is substantial even before the TS.

(3) The sharp increase in the $\mathrm{C}-\mathrm{H}$ bond length is correlated with a sharp decrease in the $\mathrm{Ir}-\mathrm{H}-\mathrm{C}$ angle at $S_{\text {total }} \approx 1$ bohr $\mathrm{amu}^{1 / 2}$ (Figure $3 \mathrm{~b}$ ). Calculation of Mulliken atomic charges shows that the "break point" at $S_{\text {total }} \approx 1$ bohr amu $1 / 2$ is roughly coincident with a decrease in the charge on the methane fragment. The calculated charge on the methane fragment is +0.14 in the adduct ( $3 a$ ) and increases to a value of +0.45 in the TS region, after which it decreases toward the value of +0.22 that is obtained in the product (4a). Gordon and Ganos8 have studied the IRC for a main-group analogue of this reaction $\left(\mathrm{H}_{2} \mathrm{E}+\mathrm{CH}_{4} \rightarrow \mathrm{H}_{3} \mathrm{E}-\right.$ $\mathrm{CH}_{3}$ ) and interpreted it in terms of a two-stage mechanism: an electrophilic, early stage (dominated by donation from $\sigma_{\mathrm{CH}}$ to a vacant $\mathrm{EH}_{2}$-based $\mathrm{MO}$ ) followed by a nucleophilic, later stage (dominated by backdonation from an occupied $\mathrm{EH}_{2}$ orbital to $\sigma^{*}{ }_{\mathrm{CH}}$ ). In light of the Saillard-Hoffmann ${ }^{13}$ model of $\mathrm{M} / \mathrm{C}-\mathrm{H}$ bonding, the positive charge on the methane fragment at all stages between methane adduct and methyl(hydride) product indicates that forward donation from a $\mathrm{C}-\mathrm{H}$ bonding $\mathrm{MO}$ to a vacant metal-based $\mathrm{MO}$ is greater than backdonation from an occupied

(57) Kubas et al. have concluded from analysis of neutron diffraction structures of $\eta^{2}-\mathrm{H}_{2}$ complexes "that the reaction coordinate for $\mathrm{H}-\mathrm{H}$ bond breaking shows relatively little change in $\mathbf{H}-\mathbf{H}$ distance until bond rupture is quite imminent, presumably when increased backbonding can no longer be tolerated." These deductions are consistent with this analysis of the IRC for the related C-H oxidative addition reaction. Kubas, G. J.; Burns, C. J.; Eckert, J.; Johnson, S. W.; Larson, A. C.; Vergamini, P. J.; Unkefer, C. J.; Khalsa, G. R. K.; Jackson, S. A.; Eisenstein, O. J. Am. Chem. Soc. 1993, 115, 569.

(58) Gordon, M. S.; Gano, D. R. J. Am. Chem. Soc. 1984, 106, 5421. 


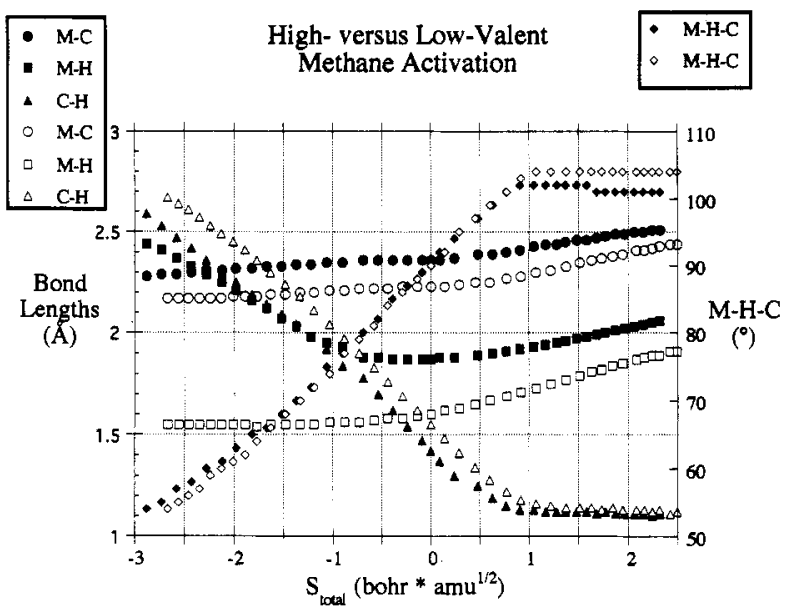

Figure 5. Calculated bond length and bond angle changes along the IRC for conversion of the $\mathrm{W}(=\mathrm{NH})_{3}\left(\eta^{2}-\mathrm{HCH}_{3}\right)$ adduct into $\mathrm{W}(=\mathrm{NH})_{2-}$ $\left(\mathrm{NH}_{2}\right)\left(\mathrm{CH}_{3}\right)$ (filled points) and $\operatorname{Ir}\left(\mathrm{PH}_{3}\right)_{2}(\mathrm{H})\left(\eta^{2}-\mathrm{HCH}_{3}\right)$ into $\operatorname{Ir}\left(\mathrm{PH}_{3}\right)_{2-}^{-}$ $(\mathrm{H})_{2}\left(\mathrm{CH}_{3}\right)$ (open points).

metal-based MO to a C-H antibonding MO all along the oxidative addition IRC. The increasing positive charge on the methane fragment as the adduct moves toward the TS indicates that donation is increasing relative to backdonation; the decreasing charge after the "break point" at $S_{\text {total }}=1$ bohr amu ${ }^{1 / 2}$ suggests that the reverse situation applies in the later stages of oxidative addition. Combining these threads leads to the conclusion that although donation of electron density from methane to metal is essential for formation of an adduct, it is not until significant population of $\sigma^{*} \mathrm{CH}$ occurs that $\mathrm{C}-\mathrm{H}$ is cleaved. ${ }^{59}$

One intriguing result which emerged from the experimental reaction coordinate ${ }^{27}$ is that both low- and high-valent, agostic complexes fit on the same trajectory, although occupying different positions along the reaction coordinate. To more closely probe the similarities between a typical $\sigma$-bond metathesis IRC and the present oxidative addition one, we have plotted both on the same reaction coordinate (Figure 5). The $\sigma$-bond metathesis IRC is that for the reaction $\mathrm{W}(=\mathrm{NH})_{3}+\mathrm{CH}_{4} \rightarrow \mathrm{W}(=\mathrm{NH})_{2}\left(\mathrm{NH}_{2}\right)$ $\left(\mathrm{CH}_{3}\right)$. The tungsten IRC shows the same features discussed at length in previous computational studies of methane activation by imido complexes. ${ }^{18 a-c, 60}$ A W example was chosen, since the metallic single-bond radii of $\mathrm{W}(1.30 \AA)$ and $\operatorname{Ir}(1.27 \AA)$ are roughly the same. ${ }^{33}$

The resemblance of the oxidative addition IRC (Figure 3a) to the $\sigma$-bond metathesis IRC (Figure 5) is striking and suggests a good degree of similarity between $\mathrm{C}-\mathrm{H}$ activation mechanisms, particularly early on in the reaction coordinate in the vicinity of the methane adduct $\left(S_{\text {total }} \geq 1\right.$ bohr amu ${ }^{1 / 2}$, Figure 5). ${ }^{61}$ In a study of methane adducts of high-valent complexes, ${ }^{40} \eta^{2}-\mathrm{CH}$ coordination was also found to be preferred. For both $\sigma$-bond metathesis and oxidative addition, $\mathrm{M}-\mathrm{C}$ bond lengths in the transition state $\left(S_{\text {total }}=0\right.$ bohr amu $\left.{ }^{1 / 2}\right)$ are close to the values they assume in the product (Figure 5). Significant M...C bond formation has been inferred in the TS for $\mathrm{C}-\mathrm{H}$ oxidative addition by 14 -electron complexes ${ }^{11}$ from selectivity patterns. Extensive M...C interaction in the $\sigma$-bond metathesis TS (Figure 3a) should also allow one to engineer an alkane functionalization catalyst

(59) (a) It is worth noting that all partitioning of the total electron density is arbitrary, although one expects trends in properties to be more reliable than absolute numbers. (b) Stretching the $\mathrm{C}-\mathrm{H}$ bond and closing the $\mathrm{M}-\mathrm{H}-\mathrm{C}$ angle should greatly increase the effectiveness of metal to $\sigma^{*} \mathrm{CH}$ backdonation. See ref 13 , in particular Table II.

(60) Full details of the reaction $\mathrm{W}(=\mathrm{NH})_{3}+\mathrm{CH}_{4} \rightarrow \mathrm{W}(=\mathrm{NH})_{2}$ $\left(\mathrm{NH}_{2}\right)\left(\mathrm{CH}_{3}\right)$ are to be published in a future contribution. $\mathrm{C}-\mathrm{H}$ activation by high-valent, group IVB imido complexes is discussed in ref $18 \mathrm{a}$.

(61) Labinger et al. have made a similar proposal based on experimental results for $\mathrm{Pt}^{11}$-mediated alkane oxidations. Labinger, J. A.; Herring, A. M.; Lyon, D. K.; Luinstra, G. A.; Bercaw, J. E.; Horváth, I, T.; Eller, K. Organometallics 1993, 12, 895 . built on a high-valent imido active species which will permit control of selectivity through judicious choice of ancillary ligands. The $\mathrm{M}-\mathrm{H}$ distances show distinctly different behavior along the IRC for the two mechanisms; this is not surprising, since in oxidative addition the $\mathrm{H}$ ends up coordinated to the metal and in $\sigma$-bond metathesis it is coordinated to a ligated atom. For $\sigma$-bond metathesis the importance of the $\mathrm{M}-\mathrm{H}$ interaction in moderating the energetics of the transition state has been discussed. ${ }^{18 a-c}$ However, in both cases the M-H distance in the TS is only slightly longer than a typical metal-terminal hydride bond length.

The most interesting of the similarities between oxidative addition and $\sigma$-bond metathesis IRCs (Figure 5) is the same correlation between the abrupt increase in $\mathrm{C}-\mathrm{H}$ distances and the sharp decrease in $\mathrm{M}-\mathrm{H}-\mathrm{C}$ angle. The same pattern of increasing charge on the methane fragment, followed by a decrease in the methane charge near this "break point" $\left(S_{\text {total }} \approx 1\right.$ bohr $\mathrm{amu}^{1 / 2}$ ) is seen for the high-valent system; however, it is not as dramatic as in oxidative addition, as expected since backdonation from the metal will be minimal for an electrophilic, $d^{0}$ complex. The frontier orbitals of this imido (and others we have studied ${ }^{18}$ ) are metal-nitrogen $\pi$ bonds, making them a potential source for electron density. Thus, while the metal acts as an electrophile in $\sigma$-bond metathesis and oxidative addition (which the calculations indicate is essential for adduct formation), the difference lies in the moiety which acts as nucleophile (donating to $\sigma^{*} \mathrm{CH}$ which is crucial to cleavage of the $\mathrm{C}-\mathrm{H}$ bond). The nucleophiles in oxidative addition and $\sigma$-bond metathesis are, of course, the metal and a polarized metal-ligand bond which directs the $H$ in the $\mathrm{C}-\mathrm{H}$ bond being activated to its eventual position. A twostage $\mathrm{C}-\mathrm{H}$ activation process provides an explanation for the similarity seen in the early part of the activation mechanism, since it is here that electron donation from substrate to metal is crucial for adduct formation for both types of methane-activating complexes. More work is needed to probe these conclusions for a wider variety of $\mathrm{C}-\mathrm{H}$-activating complexes; such research is currently underway in our lab.

\section{Summary}

An effective core potential, parallel supercomputing study of methane activation by oxidative addition was carried out for the 14-electron complexes $\mathrm{Ir}\left(\mathrm{PH}_{3}\right)_{2}(\mathrm{X}), \mathrm{X}=\mathrm{H}, \mathrm{Cl}$. Several conclusions have been reached which are summarized below.

(1) Effective core potentials have again shown their ability to describe the bonding and structure of a transition metal system. ${ }^{18}$ The coupling of this new methodology with emerging technologies like parallel computing will continue to expand the ability to probe interesting chemistry in all regions of the Periodic Table. Given the importance of the transition metals (and lanthanides) in catalysis and advanced materials, such efforts are clearly warranted.

(2) Initial interaction of methane with the activating complexes is in line with previous computation and experiment. The chloro adduct is found to be more strongly bound (by $\approx 9 \mathrm{kcal} \mathrm{mol}^{-1}$ ) due to electronegative $\mathrm{Cl}$ making the complex a better acceptor for $\sigma_{\mathrm{CH}}$ density.

(3) Metal-carbon bond formation is substantial in the TS, as suggested by experiment. ${ }^{11}$ Additionally, $\mathrm{Ir}-\mathrm{H}$ bonding in the transition state is also substantial. Thus, the main energetic expenditure in the TS region comes from scission of the $\mathrm{C}-\mathrm{H}$ bond.

(4) Analysis of the intrinsic reaction coordinate shows good agreement with the experimental trajectory of Crabtree et al. ${ }^{27}$ The most interesting observation is the correlation between an abrupt increase in $\mathrm{C}-\mathrm{H}$ bond distance and a decrease in $\mathrm{M}-\mathrm{H}-\mathrm{C}$ angle. Analysis of the wave functions shows that the methane fragment which had been growing more positively charged up to this point starts to accept electron density and become less positively charged. In view of the Saillard-Hoffmann ${ }^{13}$ model 
of $\mathrm{M} / \mathrm{C}-\mathrm{H}$ bonding, we interpreted this in terms of a two-stage $\mathrm{C}-\mathrm{H}$ activation mechanism: substrate to complex donation is important in the early stages of the reaction (electrophilic stage) while complex to substrate backbonding is necessary later in the reaction (nucleophilic stage) for $\mathrm{C}-\mathrm{H}$ bond breaking.

(5) Comparison of the intrinsic reaction coordinate for a lowand high-valent methane activation reaction showed surprisingly similar topology in the early portion of the $\mathrm{C}-\mathrm{H}$ activation process. Differentiation between the two mechanisms occurs in the region in the TS at the point at which there is a shift from the electrophilic to nucleophilic stage.

Acknowledgment. The National Science Foundation (through its support of the National Center for Supercomputing Applications, Grant No. CHE920027N), Petroleum Research Fund (administered by the ACS), Oak Ridge National Laboratory (for allowing access to the iPSC/860 at ORNL through our collaboration with the Joint Institute for Computational Science at University of Tennessee-Knoxville), IBM (participation in the Developer's Discount Program), and the Air Force Office of Scientific Research (Grant 93-10105) are acknowledged for support of computational transition metal chemistry at Memphis State. Our appreciation of various aspects of $\mathrm{C}-\mathrm{H}$ activation by low-valent complexes has profited greatly from discussions with Profs. Robert H. Crabtree (Chemistry, Yale) and William D. Jones (Chemistry, Rochester). We also acknowledge the communication of ref 61 by Prof. John E. Bercaw (Chemistry, CalTech) before publication. The assistance of Prof. Mark S. Gordon and the Ames Lab/Iowa State Quantum Chemistry group, in particular Mike Schmidt and Theresa Windus, in implementing parallel-GAMESS on the iPSC/860 at ORNL was invaluable. 